\title{
TERAPIA INTENSIVA
}

\author{
Abordagens das \\ práticas protissionais
desenvolvidas no setor
}

Francisco Lucas de Lima Fontes ORGANIZADOR 